\title{
On the Construction of Multi - modal Interactive Teaching Mode of "Internet + Business English"
}

\author{
Zheng Jing ${ }^{1, \text { a }}$ \\ ${ }^{1}$ Jiangxi Science \& Technology Normal University, Nanchang, Jiangxi, 330013, China \\ aluannezheng@hotmail.com
}

Keywords: "Internet +"; multi-modal; interactive teaching model;

\begin{abstract}
With the development of social science and technology, the continuous progress of information technology, China's Internet era gradually started, and in recent years has developed into the "Internet +" era, the so-called "Internet +" is actually using the Internet platform, the Internet With the industry in-depth integration, so as to create a new development, which represents a new social form, to fully play the Internet and economic and social integration, improve the teaching of innovation and teaching rate, for the community Provides a more convenient and efficient network platform channel, the article from the traditional business English teaching problems, put forward the "Internet + Business English" multi-modal interactive teaching model.
\end{abstract}

\section{Introduction}

With the development of society, the economy becomes more international, and as the most important second language English has become the most important means of communication, and business English in addition to the need for professional English level, but also should have spoken language, translation, etc. Skills, so for the teaching of business English, in order to achieve internationalization, the colleges and universities began to "Internet +" era into the teaching, the use of the Internet for integration of teaching, the article from the traditional teaching model problems, put forward "Internet + business English "in the multi-modal interactive teaching model to enhance the relationship between teachers and students to improve students' awareness and interest in self-learning, so as to improve the quality of teaching for the country to cultivate more complex talents.

\section{The problems in the traditional teaching process}

2.1 The curriculum is not advancing with the times

Traditional business English is mostly "foreign trade correspondence", "business negotiations" and other courses mainly around the traditional international trade, but with the development of society, the economic status has become diversified, the gradual emergence of B2B , C2C, B2C as the main mode of import and export trade, and with the development of these main models, the community of this type of talent needs to be improved, but many college business English students are not enough understanding, leading to not real So that docking, reducing the efficiency of teaching at the same time also reduce the supply of talent, reducing the speed of development in China.

2.2 Business English teaching content can not be used

Business English is fundamentally a professional in English teaching, and in the community was a special application, but many colleges and universities are still practical traditional business English teaching materials, so many teachers in the business knowledge of the time, But for the emergence of new vocabulary and terminology in the new era, but did not communicate in a timely manner, resulting in students engaged in the relevant occupation, because the professional knowledge, however, professional terms can not be used, resulting in embarrassing employment scene, Reducing the employment rate 


\subsection{The teaching method is boring and lacks the interaction}

Although the education reform, a lot of teaching methods are used by teachers, but there are still a lot of teachers, in the teaching of habitual extension of the traditional teaching methods, in the classroom to teachers to explain the knowledge, students can only Passive acceptance of teaching knowledge, and even serious lack of interaction between teachers and students, resulting in students in the classroom can not participate in teaching, and even occasionally because the teacher is talking about the phenomenon of students, students can not be learned in time to absorb the knowledge Use, resulting in students after employment is not clear the steps, thereby improving the student's unemployment rate.

\subsection{The teacher itself is not professional}

Business English teaching is a very special subject, in the course of teaching not only English teaching, but also both foreign trade teaching, so business English is a combination of foreign trade and English teaching mode, so in the course of teaching But also need a professional skills of teachers to teach, but now many college teachers are simply engaged in English education, business knowledge is not only not familiar with, and did not practice, so that students only learned English, but ignored The business teaching, resulting in misleading the direction of employment of students, reducing the output of business talent

\section{Internet + Business English "multi - modal interactive teaching mode}

\subsection{Create a relevant business English learning situation}

The Internet has become an inevitable tool for social development, and the usefulness of the Internet itself is very powerful, so teachers can use the Internet to set the learning situation, for example, in the business correspondence teaching, teachers can use Internet technology to the scene In the courseware to play the relevant business correspondence, and then ask the students can see the content, and then teachers one by one in the courseware on the students said the content, then set the scene to teach, through the Internet teacher Some materials, students set up according to the discussion of the exchange of the scene, and encourage students to write their own hands to mobilize the enthusiasm of students to learn to improve the interaction between teachers and students.

\subsection{The creation of a network teaching system}

The application of the Internet is through a variety of computer software systems, so teachers can create a network through the Internet teaching system, as well as a variety of learning sites, students can visit the site at any time you want to understand the course, for example, "business negotiations "Teaching content, one by the teacher through the creation of network teaching system for teaching, and in the teaching process of video retention; Second, teachers in the network teaching platform, with their students can be real-time interaction; the teaching process retained a video, you can easily watch the secondary students a deeper impression. In addition, through the Internet, teachers can also set an anonymous question area and the proposed area, in this area, students can be questionlessly questioned, even if there is no longer a simple question to worry about someone jokes, teachers in the background answers, in order to raise the level of teaching and improve the interaction between teachers and students [3].

\subsection{Create life and Discussion}

Teachers in the creation of network system teaching, students can arrange a variety of after-school homework, or the students into several groups, the Internet online discussion mode, such as the community more innovative business terms B2B and B2C, teachers allow students to Under the class through the Internet for information search, from the information to find B2B and B2C features, platforms, and even teachers can also carry out a network debate on the Internet, for example, "B2B and B2C which the development prospects are better? Or "B2B and B2C which is easier to do some?" And so on, using a similar issue to discuss the students on the network will naturally be divided into two camps, and then start a heated discussion, then the teacher and then immediately on this topic to start teaching, So that students not only in the pre-class have their own understanding of the two, but also launched a heated discussion, in general, the general characteristics of the two have been 
understood, so the teacher in the teaching process You can expand the teaching on this point, so that students understand the benefits of both, it will be easier for students By fresh content, improve their absorption capacity and the ability to discuss.

3.4 The development of the Internet excellent resources

The existence of the Internet can collect excellent resources around the world, understand any international business operations, but also from the Internet to collect a variety of related business content, including a variety of business information consulting, business news, and even related Of the business law, import and export trade and other resources, knowledge teaching is not limited to textbooks, so teachers in the teaching of the time, through the Internet to introduce a variety of excellent resources for teaching. For example, in the relevant business English language teaching, teachers can use the Internet to find some commonly used business English conversation words, such as "I've heard so much about you.", In the application of the general said " Is often used for the first time to meet each other, but often hear the words of the other side of the words; and then "Distinguished / Honorable or Respected friends!" In business conversation, generally used for international embassies Meeting is called "you" for, etc., need teachers through the Internet to develop excellent resources for teaching, this way, not only the teacher's teaching level has improved, but also has opened up the students' knowledge, improve the The quality and efficiency of teaching.

\section{Summary}

In short, the "Internet" era has entered the "Internet +" era, in business English teaching can continue to use the "Internet + Business English" teaching methods to improve the quality of teaching, the article from the traditional teaching methods of curriculum planning With the times, business English teaching content can not be practical, teaching methods boring, lack of interaction and the teacher itself is not professional and other issues, put forward to create the relevant business English learning situation, create a network teaching system, create And the development of Internet excellent resources and other models for "Internet + Business English" interactive teaching, improve the level of business English teaching and efficiency.

This article is one of the research results that 2016 Jiangxi Science \& Technology Normal University level teaching reform project - "masking teaching method in undergraduate business English courses" (NO: JGYB-16-78-22)

\section{References}

[1] Li Danqian. "Internet +" era of integrated business English courses SPOC mixed teaching model research [J]. Journal of Kaifeng Institute of Education, 2016,11: 126-127.

[2] Yang Cheng-qing. Discussion on the Curriculum Construction of Higher Vocational Colleges in the Internet + "A Case Study of Business English Majors in Zhejiang Changzheng University [J]. Vocational Education, 2016,05: 16-19.

[3] Gao Peng. Study on the Teaching Model of Business English Translation in Higher Vocational Education Based on "Internet +" [J]. Journal of Hubei Correspondence University, 2016, 17: 122-123.

[4] Ma Liyan. "Internet +" under the vocational English professional students innovative entrepreneurial ability training [J]. Journal of Heilongjiang College of Education, 2017,04: 52-54. 